\title{
Legal Feminism and the UN's Gender Mainstreaming Policy: Still Searching for the Blind Spot?
}

\section{Seryon Lee*}

This article primarily assesses feminism's achievements and challenges, particularly within the framework of the UN gender mainstreaming policy. The first part of the article explored different feminist inquiries into general law to question whether such inquiries have been successfully or properly reflected in the UN gender mainstream process. The second part focused on the progress made by the UN Security Council through its series of resolutions on Women, Peace and Security to examine the ways in which international institutions and international legal categories tend to exclude women and the issues of most concern to women. This analysis, owing much to the extensive literatures on female analyses on international law in the last two decades, led to the conclusion that despite the significant progress that has been made by feminist international lawyers, there remain many ongoing challenges before international law may fully embrace and reflect 'true' feminist values.

\section{Keywords}

Liberal Feminism, Gender Mainstreaming, SC Resolution 1325, SC Resolution 1820, Beijing Declaration 


\section{Introduction}

As a result of enthusiastic studies and practices of legal feminism for the past centuries, ${ }^{1}$ all the major human rights treaties since 1945 have recognized gender equality before the law. However, it was not until the 1990s that the issues concerning violence against women featured seriously on the agenda of the international community. ${ }^{2}$ Although belated, such enlightenment is partially due to the atrocities committed against women in former Yugoslavia and Rwanda in the early 1990s. It is scarcely an exaggeration to say that the article on "Feminist Approaches to International Law" ${ }^{3}$ by three eminent international law scholars marked the beginning of vigorous feminist analyses in international law. Thereafter, it paved the way for active 'feminist' engagement, particularly within the context of international law for the past two decades.

This article contends that "international law is a gendered system," which marginalizes women's interests in a privileged, virtually men's world. ${ }^{4}$ Since then, different feminist inquiries into international law have generated notable achievements, especially in the protection of international human rights. However, feminist discussion seems to occupy a niche area, as Charlesworth acknowledged, so that the feminist debate may have yet attracted little engagement from the international community. ${ }^{5}$ She persuasively points out that masculinity has been firmly integrated in the mainstream of international law. It is indeed difficult to find any "masculinist perspective on international law." Moreover, it is fairly regrettable to note that "when women appear in the international sphere they are either playing the male role like Margaret Thatcher or are the quintessential victim in need of male protection." In other words, the key to feminist debate lies in the fact that women

1 In 1792, Mary Wollstonecraft had already advocated for the women's right to be educated in her classic book, A VINDICATION OF THE RIGHTS OF WOMAN. Women's suffrage movement prevailed throughout the nineteenth and early twentieth centuries. N. Lacey, Feminist Legal Theory and the Rights of Women, in Gender AND Human Rights 13-14 (K. Knop ed., 2004).

2 A. Edwards, Violence Against Women: Under International Human Rights Law 7 (2011).

3 H. Charlesworth, Christine Chinkin and Shelly Wright, Feminist Approaches to International Law, 85 Am. J. INT'L L. 618-645 (1991).

4 Id. at 614-615.

5 H. Charlesworth, Talking to Ourselves: Should International Lawyers Take a break from Feminist? in FEMINIST Perspectives on Contemporary International Law 17 (S. Kouyo \& Z. Pearson eds., 2011).

6 H. Charlesworth, Feminist Ambivalence about International Law, 11 InT'L LEgAL THEory 1 (2005).

7 R. Saloom, A Feminist Inquiry into International Law and International Relations, 12 Roger Williams U. L. ReV. 169 (2006). E.g., women are portrayed more or less as victims in number of international instrument including the 
are often excluded, marginalized, silenced, misrepresented or victimized. ${ }^{8}$

The diverse values that emerged from feminism methods of international law culminated in the adoption of Beijing Declaration and Platform for Action at the Fourth World Conference on Women in $1995 .{ }^{9}$ Almost all the major postwar human rights instruments proclaim and affirm the equal rights of men and women. ${ }^{10}$ It was only until the declaration of the Beijing Platform for Action, however, which called for the women's full participation on an equal basis with men in all spheres of life as well as in all levels of power and decision-making process across the world. ${ }^{11}$ Another breakthrough came in 2000 with the adoption of the UN Security Council Resolution 1325 on Women, Peace, and Security. ${ }^{12}$ It was a consequence of the persistent efforts of anti-war feminist advocates in coalition with other relevant NGOs. ${ }^{13}$ The unanimous adoption of Resolution 1325 marked the starting point of 'gender mainstreaming' in the UN policies. Resolution 1325 invited the UN Secretary-General to conduct a study on the impact of armed conflict on women and girls, the role of women in peace-building and the gender dimensions of peace processes and conflict resolution. ${ }^{14}$ However, it took almost another decade to address the issues of women, peace and security at the level of the Security Council. Resolution 1325 was followed by a series of significant resolutions adopted between 2008 and 2010 concerning women in armed conflicts. ${ }^{15}$ Though these resolutions undoubtedly function as firm ground to protecting and empowering women in a particular situation, they reveal some drawbacks which will be discussed in the

Protocol Additional to the Geneva Conventions 1949 and Relating to the Protection of Victims of International Armed Conflicts, which reads, in Article 76 that: "Women shall be the object of special respect and shall be protected in particular against rape, forced prostitution and any other form of indecent assault." Moreover, the Geneva Convention Relative to the Treatment of Prisoners of War regards women prisoners particularly in Articles 29, 88 \& 110 , as subclass of prisoners who require separate care and special protections.

8 Supra note 2, at 2.

9 UN Report of the Fourth World Conference on Women in Beijing 1995, U.N. Doc. A/CONF.177/20/Rev.1, available at http://www.un.org/womenwatch/daw/beijing/pdf/Beijing\%20full\%20report\%20E.pdf (last visited on Sept. 1, 2013). The UN Fourth World Conference on Women: Action for Equality, Development and Peace (hereinafter Beijing Declaration and Platform for Action) is the continuation and acceleration of a process begun in 1975, which was designated as "International Women's Year."

10 See, e.g., Universal Declaration of Human Rights; International Covenant on Civil and Political Rights; and International Covenant on Economic, Social and Cultural Rights.

11 See Beijing Declaration and Platform for Action 913.

12 S.C. Res. 1325, U.N. Doc. S/Res/1325 (2000).

13 D. Otto, Power and Danger: Feminist Engagement with International Law through the UN Security Council, 32 Australian Feminist L. J. 100 (2010).

14 Supra note 12.

15 S.C. Res. 1820, U.N. Doc. S/RES/1820 (2008); S.C. Res. 1888, U.N. Doc. S/RES/1888 (2009); S.C. Res. 1889. U.N. Doc. S/RES/1889 (2009). S.C. Res. 1960, U.N. Doc. S/RES/1960 (2010). 
article.

This research seeks to examine the feminist perspectives on international law and ascertain how such values are reflected in gender mainstreaming progress within the UN through the assessment on the achievements and challenges ahead. This article is composed of five parts including Introduction and Conclusion. Part two will present different contentions among feminist scholarships in international law. Part three will explore the progress and development of the UN gender mainstreaming policy. Part four will discuss the challenges remaining as feminist ideas continue to be instrumentalized at the international level.

\section{Feminist Scholarship in International Law}

\section{A. General Overview}

In the last two decades, there have been extensive feminist discussions on international law with voluminous literatures raising women's voice in legal and political context. However, the term 'feminism' or 'feminist' is often negatively portrayed in the media and even generates ambiguous attitudes towards feminism among women, because such terms are erroneously associated with negative connotation or some form of radicalism. ${ }^{16}$ Generally speaking, the feminist legal scholarship was accepted only on the condition that they were to be 'invited' to raise 'women's voice,' but not to challenge the conventional structure of international law. ${ }^{17}$ Such dual goals of searching for the blind spot and challenging the existing institution inevitably generated tension between "resistance and compliance" in the feministic perspective of international law. ${ }^{18}$

Thereby, Charlesworth identified two different roles of feminist analysis. She referred to one as 'deconstructive' and the other as 'reconstructive. ${ }^{19}$ She also

16 D.Beck, The “F” Word: How the Media Frame Feminism, 10 Nat'L Women's Stud. Ass'n J. 139 153 (1998); P. Aronson, Feminist or Postfeminists?: Young Women's Attitudes towards Feminism and Gender Relations, 17 GENDER \& Soc'y 912 913 (2003). Aronson observed that the survey on the attitudes towards feminism showed that more than half of the women interviewees did not want to explicitly define themselves in relation to feminism at all and failed to classify themselves as either feminists or non-feminists.

17 S. Kouvo \& Z. Pearson, Introduction, in Feminist Perspectives on Contemporary International Law 3-5 (S. Kouyo \& Z. Pearson eds., 2011).

18 Id.

19 H. Charlesworth, Feminist Critiques of International Law and Their Critics, 13 ThiRd World Legal Stud. 2-3 (1995). 
reconfirmed an uneasy coexistence of the dual commitment of feminist methods. ${ }^{20}$ In accordance with Charlesworth, deconstructive techniques are based on the presumption that almost all human rights law has been created by men so that such 'men's human rights' may directly challenge the 'universality' of international human rights. ${ }^{21}$ The discussion of public and private dichotomy in international human rights is relevant to the argument that human rights laws generally operate in the public sphere, which has been predominantly inhabited by men, resulting in statistically imbalanced representation of women. ${ }^{22}$ Insofar as a feminist reconstruction of international human rights in concerned, it does not necessarily mean the entire breakdown of the public and private distinction; it rather means more responses to women's concerns because a key feminist concern is that any type of distinction does not devalue women's experiences. ${ }^{23}$

Another crucial issue in feminist scholarship is the identification of a distinctive woman's voice that is often underestimated by referring to terms like "ethic of care" and "ethic of justice used by psychologist Gilligan." ${ }^{24}$ Gilligan's research into childhood development disclosed that young girls displayed very different reactions from boys when they were asked to solve a moral dilemma. ${ }^{25}$ It was observed that girls invoked a so-called "ethic of care" by perceiving things in terms of relationship, responsibility, caring and communication. The boys relied more on "an ethic of justice" by analyzing problems in terms of right and wrong, fairness, and rationality. ${ }^{26}$ Thus, traditional psychological theory arguably contemplates that the male pattern of reasoning is more advanced than the female's. However, the author agrees that such terms overgeneralize the difference between women and men; they even ignore the difference among women themselves, not to mention negligence of any relevance with law. ${ }^{27}$

\section{B. Different Categories}

While the feminist inquiry into international law fundamentally embraces the inherent tension between resistance and compliance as a common denominator,

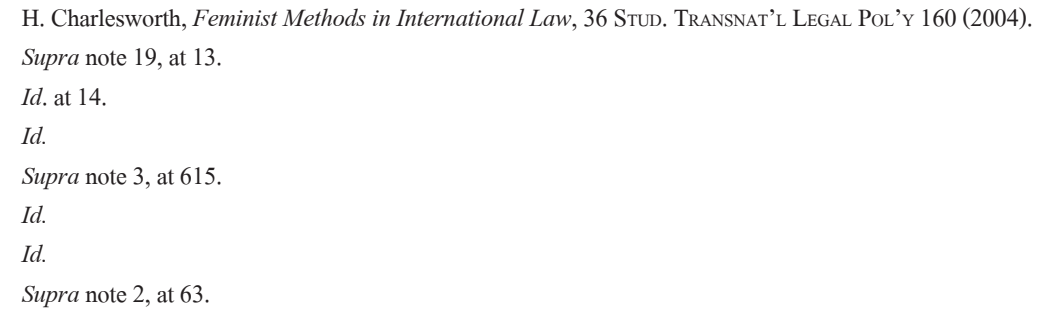


different views do prevail among the female scholarships. Feminist scholarships are typically divided into different categories such as liberal, cultural, social and radical feminism. ${ }^{28}$ First, liberal feminism is based on liberal political thought. ${ }^{29}$ It favors compliance over resistance as it advocates reform as opposed to a total eradication of the status quo. ${ }^{30}$ Classical liberalism emphasizes on minimal State interference to maximize individual's freedom. Similarly, liberal feminists focus on eliminating formal barriers to fully realize the equality of opportunity between men and women. ${ }^{31}$ However, liberalism is often criticized for its emphasis of 'individualism.' 32 The liberalist would argue that women's equal representation is a question of justice and fits alongside feminist challenges to exclusion and will acknowledge that women have a different set of values, experiences, and expertise. ${ }^{33}$ However, women's relative underrepresentation in various fields of occupation may be due to individual choices. ${ }^{34}$ It is thus noteworthy to consider whether women as a group can fit into the model of individual rights. Another criticism faced by liberalism is related to the concept of freedom as freedom under liberalism is usually associated with being freed from the State rather than positively exercising freedom. ${ }^{35}$ Liberalism is also severely attacked where the distinction is drawn between the public and private spheres for the purposes of international legal rules. Charlesworth recognizes such distinction, especially in international human rights law and categorizes State action as 'muscular.' ${ }^{36}$ Many other scholars sharing this view argue that international human rights law is based on a dichotomy between State and non-State action that relegates women to the private sphere. ${ }^{37}$ Likewise, Saloom contends that: "Masculinity is deeply entrenched in the international

28 N. Kim, Towards a Feminist Theory of Human Rights: Straddling the Fence between Western Imperialism and Uncritical Absolutism, 25 Colum. Hum. RTs. L. Rev. 52-55 (1993). Other various types such as cultural, post-modern or critical feminisms exist: cultural feminists believe that men and women are inherently different. Postmodern feminism does not adhere to the category of woman as a mode of analysis. They reject the notion of a stable gender identity that is fixed or essential. Critical feminist seeks to keep some semblance to the category of woman intact while realizing the shortfalls of using those categories. Social feminism emphasizes that women have social skills and qualities that are unique from those of their male counterparts, and that these qualities should be accorded the same respect. See supra note 7, at 162-163.

29 Supra note 1 , at 19.

30 Supra note 7, at 160-161.

31 Supra note 28.

32 Supra note 1, at 20.

33 Supra note 2, at 99-101.

34 Supra note 1, at 20.

35 Id. at 21.

36 Supra note 20, at 379.

37 Supra note 28, at 50. 
relations as methodologies and epistemologies of international relations are always based on so-called male attributes." 38

These arguments are all related to women's concerns in a male-privileged society. The public sphere has been consistently represented as the sphere of rationality, culture and intellectual endeavor as compared with the domestic sphere being one of nature, nurtured on-rationality. ${ }^{39}$ However, not all feminists conceptualize the public and private dichotomy in the same way. The line between public and private is quite blurry and constantly undergoes changes depending on the particular circumstances of each State. ${ }^{40}$ Moreover, though the 'State responsibility' traditionally concerned direct State action in the public sphere, even this doctrine is shifting as to recognize that States alone are not the sole source of violation of human rights. ${ }^{41}$ To the extent that the public and private distinction applies to the international legal system, it, therefore, is largely due to practicality, not to perpetuate gender oppression." ${ }^{42}$

At the opposite spectrum of liberal feminism lies radical feminism. While radical feminists accept the sexualization of the binary divisions such as male and female, they seek for the greater recognition of the emotive feminine side in social practice. In contrast, liberalist feminists emphasize that women are as capable as men in the public sphere in terms of intellectual power and objectivity. ${ }^{43}$ Therefore, the dividing line between liberal and radical feminism is an emphasis on the individualism, which is precisely summarized as "liberal feminism aggregates all women out of each women, and radical feminism sees all women in each one." ${ }^{44}$ Radical feminism is also subject to several criticisms, one of which includes its limited focus on a particular set of issues such as 'sexuality' and 'reproduction. ${ }^{45}$ Moreover, a persuasive criticism can be foreseeable as radical feminists show less interest in economic or political inequities. Some radical feminists view women's oppression as equivalent as being denied control over women's body though the use of violence, abortion restriction and reproductive technology. ${ }^{46}$ According to radical

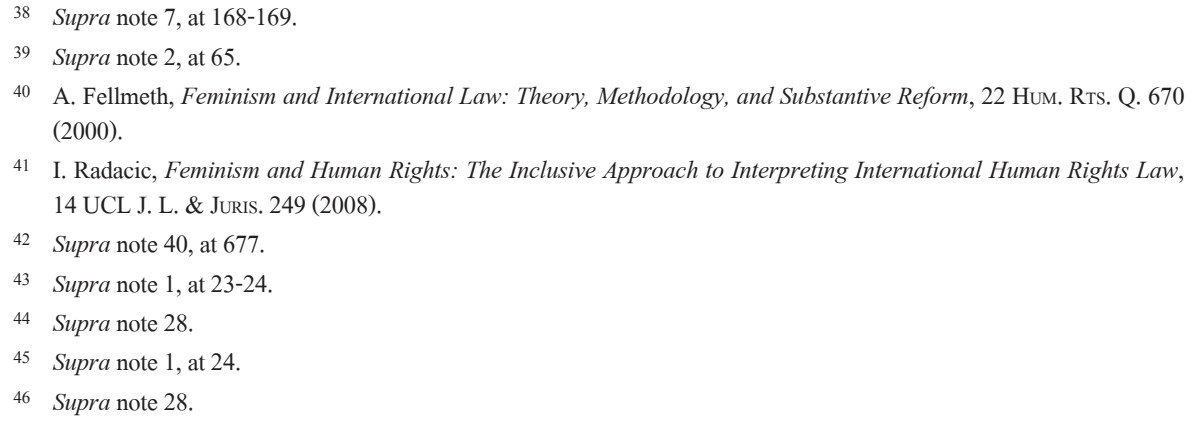


feminism, women are oppressed as a class and sexism is a system of subordination with women on the bottom and men on top. ${ }^{47}$ For this reason, removing barriers of inequality will not solve the underlying issue of gender because the existing patriarchal power structure is rarely touched upon. Instead, the complete elimination of forces that deprive women of control over their bodies will be a viable solution to realize the gender justice. ${ }^{48}$ In short, what separates radical feminism from liberal feminism is its degree of emphasis on equality and individualism as the former perceives women's oppreession as a class rather than as individuals.

\section{Gender Mainstreaming Policy in the UN}

\section{A. Definition of Gender}

Before discussion on the gender mainstreaming ${ }^{49}$ policy of the UN, it is necessary to explore the meaning of 'gender' as the word is often applied interchangeably with the word 'women' in international legal discourse. Edwards distinguishes the terms of 'sex' and 'gender' by referring to former as biological differences between women and men and the latter as the social and cultural identities that are attributed to men and women on the basis of unequal power. ${ }^{50}$ The Committee on the Elimination of Discrimination against Women ("CEDW") defines 'gender' in a more neutral way as "the social meanings given to biological sex differences." This distinction is important to ascertain whether gender specifically refers to 'discrimination' or 'exclusion' or merely indicates differences between women and men in terms of traits and social roles. As pointed out by Edwards, racial discrimination is mostly about prejudicial attributes based on economic and social nature rather than simple biological criteria. ${ }^{52}$ In this sense, the definition given by the CEDW seems to be most suitable as it embraces both biological and social attributes. In the

47 Id.

48 Id.

49 According to Charlesworth, the term mainstreaming was first used in the $1970 \mathrm{~s}$ in the context of educational literature to describe an educational method that includes many different kinds of learners in the same classroom. It describes classrooms where student with disabilities and students who do not have disabilities are taught together. H. Charlesworth, Not Waving but Drowning: Gender Mainstreaming and Human Rights in the United Nations, 18 HaRv. Hum. RTs. J. 2 (2005).

50 Supra note 2, at 13.

$51 \quad I d$.

$52 I d$. at 16. 
case of gender mainstreaming, the sex and gender distinction has been somehow blurred. Charlerworth points out that the term 'gender mainstreaming' in the UN practice shows a very limited scope of operation as is primarily relevant to policy development in particular areas such as development and human rights. ${ }^{53}$ Other fields appear immune to gendered scrutiny as gender mainstreaming mandates have not influenced either the UN International Law Commission or the International Court of Justice. ${ }^{54}$ According to the Report by the UN Economic and Social Council (“ECOSOC"), gender mainstreaming is defined as follows: ${ }^{55}$

\footnotetext{
[a] strategy for making women's as well as men's concerns and experiences an integral dimension of the design, implementation, monitoring and evaluation of policies in all political, economic and societal spheres so that women and men benefit equally and inequality is not perpetuated. The ultimate goal is to achieve gender equality
}

The UN's gender mainstreaming policies assume that 'gender' is a synonym for women, which does not seem to be technically correct. ${ }^{56}$ This is evident in the ECOSOC definition as noted above. This omission causes a number of problems. It links gender primarily with biology, implying that gender is a fixed and objective fact about a person; it does not capture the ways that gender is constructed in society to make some actions seem natural and others controversial. Overall, such definition only reaffirms the naturalness of female and male identities and bypasses the performative aspects of gender. ${ }^{57}$ Edwards maintained that "gender is not about women specifically" ${ }^{" 58}$ that it must be understood contextually by considering different roles and statuses that are attributed to men and women on the basis of unequal power. It should be further recognized that equality of women and men is necessary for social justice, development and peace.

\section{B. Basic Principles and Progress}

The principles for mainstreaming a gender perspective in the United Nations system

53 Supra note 5, at 30 .

54 Id.

55 Economic and Social Council, Report of the Economic and Social Council for 1997, U.N. GAOR, 52nd Sess., Supp. No. 3, U.N. Doc A/52/3/Rev.1/Add.1 (Sept. 18, 1997), available at http:/www.un.org/documents/ga/docs/52/plenary/ a52-3.htm (last visited on Sept. 12, 2013).

56 Supra note 49 , at 15.

57 Supra note 5, at 30-31.

58 Supra note 2, at 13. 
generally cover the following areas: ${ }^{59}$

- Issues across all areas of activity should be defined in such a manner that gender differences can be diagnosed - that is, an assumption of gender- neutrality should not be made;

- Responsibility for translating gender mainstreaming into practice is system- wide and rests at the highest levels. Accountability for outcomes needs to be monitored constantly;

- Gender mainstreaming also requires that every effort be made to broaden women's participation at all levels of decision-making;

- Gender mainstreaming must be institutionalized through concrete steps, mechanisms and processes in all parts of the United Nations system;

- Gender mainstreaming does not replace the need for targeted, women-specific policies and programmes or positive legislation, nor does it substitute for gender units or focal points; and

- Clear political will and the allocation of adequate and, if need be, additional human and financial resources for gender mainstreaming from all available funding sources are important for the successful translation of the concept into practice.

Prior to the 1990s, violence against women was mostly recognized as a domestic issue. ${ }^{60}$ Not surprisingly human rights issues were traditionally reserved for domestic matters. Also, Human Rights law does not generally extend to the private sphere of the home and family where most women live out their lives. Thus it has been difficult to persuade the international community to agree that violence against women occurring outside the public sphere constitutes a violation of human rights. ${ }^{61}$ However, in the mid-1990s serious violations of women's rights were recognized at the global level, particularly within the context of armed conflict. ${ }^{62}$ These atrocities in former Yugoslavia and Rwanda outraged the international community as women were routinely raped and forcibly impregnated as part of deliberate military strategies. ${ }^{63}$ In 1998, the International Criminal Tribunal for Rwanda, through its historic judgment in Prosecutor v. Jean-Paul Akayesu, became the first international tribunal to define rape as "an act of genocide" and to find "an individual guilty

59 Supra note 55.

60 Supra note 2, at 7. Edwards further notes that international instruments relating to violence against women existed as early as 1905 , but those instruments were highly criticized for their protective nature, rather than addressing the empowerment of women.

61 Supra note 19, at 14.

62 Supra note 2, at 7.

63 Id. 
of genocide" on the basis, inter alia, of acts of rape and sexual violence. ${ }^{64}$ The International Criminal Court ("ICC") along with ICTY and ICTR recognized acts of sexual violence as a crime of genocide, crime against humanity and war crimes. ${ }^{65}$ However, all three categories of international crimes are concerned only with acts that form part of a widespread, systematic or large-scale attack.

The other UN human rights treaty bodies have approached the issue of violation against women by different degrees. The Declaration of the Elimination of Violence against Women ("DEVAW") was adopted in $1993^{66}$ and drew attention as violence against women became an international concern. While the violence against women firmly abuses fundamental rights of women, 'women' rights' have seldom been categorized as a human rights issue. ${ }^{67}$ Once again, all efforts were made to bring out the women's voice at the global level, which subsequently led to the adoption of the Beijing Declaration and Platform for Action in 1995. ${ }^{68}$ The Beijing Declaration ensured "the full implementation of the human rights of women and of the girl child as inalienable, integral and indivisible part of all human rights. ${ }^{\circ 9}$ Also, it highlighted particular harms not specifically mentioned in DEVAW, including systematic rape, forced abortion and forced pregnancy during armed conflict. Although the Beijing Declaration is neither binding in nature, nor provides any enforcement mechanism, it is the most comprehensive statement about the women issues. In particular, the twelve "Critical Areas of Concern" provide the following issues: poverty, education, health, violence, armed conflict, the economy power and decision-making, mechanisms for women's advancement, women's human rights, mass media, the environment, and the girl child. ${ }^{70}$

\section{Security Council Resolutions on Women, Peace and Security}

The UN Security Council has also made notable progress by adopting Resolution 1325 on Women, Peace and Security Resolution on October 31, 2000, ${ }^{71}$ which was welcomed by many feminist scholars and often described as "a success story for

\footnotetext{
64 Prosecutor v. Akayesu, Case No. ICTR-96-4-T, Sept. 2, 1998, ch. 6.3.1., at 496.

65 Rome Statute arts. 7(1)(c), (g), (h) \& 8(1)(b)(xxii).

66 G.A. Res. 48/104, U.N. Doc. A/RES/48/104 (Dec. 20, 1993), available at http://www.un.org/documents/ga/res/48/ a48r104.htm (last visited on Sept. 21, 2013).

67 Id.

68 Supra note 9.

69 For details, see Beijing Declaration and Platform for Action, 99.

70 Id. at $9943-46$.

71 Supra note 12.
} 
gender mainstreaming." ${ }^{" 72}$ Resolution 1325 reaffirms the important role of women in all stages of conflicts, including peace negotiations, peace-building, peacekeeping, humanitarian response and in post-conflict reconstruction. It stresses the importance of their equal participation and full involvement in all efforts for the maintenance and promotion of peace and security.

First, Resolution 1325 urges all actors to increase the participation of women and incorporate gender perspectives in all UN peace and security efforts by calling on all parties to conflict to take special measures to protect women and girls from genderbased violence, particularly rape and other forms of sexual abuse, in situations of armed conflict as the resolution 1325 reaffirms in its preamble that:

the important role of women in the prevention and resolution of conflicts and in peacebuilding, and stressing the importance of their equal participation and full involvement... and the need to increase their role in decision-making with regard to conflict prevention and resolution

In addition, Resolution 1325 urges the Secretary-General "to appoint more women as special representatives to purse good offices"; it calls on Member States "to provide candidates to the Secretary-General for inclusion in a regularly updated centralized roster." 73 The resolution also demands the expansion of the contribution of women in UN field-based operations where they are traditionally underrepresented and especially among human rights and humanitarian personnel. ${ }^{74}$

Despite such effort to ensure gender balance, the composition of human rights treaty bodies shows no significant incremental participation of women. ${ }^{75}$ (Table 1 )

Furthermore, female representation in the UN to date is still scarce; during the period between 2000 and 2010 in the UN system, the proportion of women increased only by $6.9 \% .^{76}$ At the end of 2010 , women constituted $40.4 \%$ of all staff in the professional and higher categories (D \& P Levels) with appointments of one year or more. While women constituted $29.3 \%$ at the senior professional positions (D-1), women accounted for $57.3 \%$ and $60.2 \%$ at P-2 and P-1 level respectively,

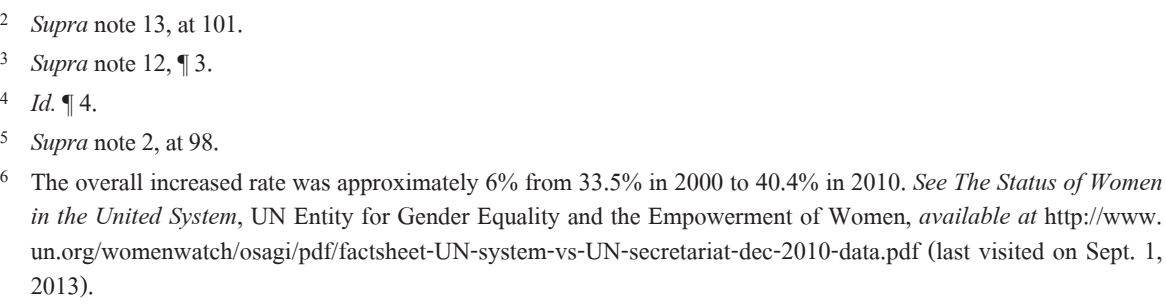
in the United System, UN Entity for Gender Equality and the Empowerment of Women, available at http://www. un.org/womenwatch/osagi/pdf/factsheet-UN-system-vs-UN-secretariat-dec-2010-data.pdf (last visited on Sept. 1, 2013). 
clearly showing that gender balance has been achieved only at the entry professional levels. ${ }^{77}$

Table 1: Progression of Membership of the Human Rights Treaty bodies ${ }^{78}$

\begin{tabular}{|l|c|c|c|c|c|}
\hline $\begin{array}{l}\text { Committee } \\
\left(1^{\text {st }} \text { session) }\right.\end{array}$ & $\begin{array}{c}\text { Total } \\
\text { Membership }\end{array}$ & $\begin{array}{c}1^{\text {st }} \text { Election } \\
\text { Men } \%\end{array}$ & $\begin{array}{c}1^{\text {st }} \\
\text { Women( } \%)\end{array}$ & $\begin{array}{c}\text { Dec.2009 } \\
\text { Men(\%) }\end{array}$ & $\begin{array}{c}\text { Dec.2009 } \\
\text { Women(\%) }\end{array}$ \\
\hline $\begin{array}{l}\text { HRC(1985) : Human Rights } \\
\text { Committee }\end{array}$ & 18 & $17(94 \%)$ & $1(6 \%)$ & $13(72 \%)$ & $5(28 \%)$ \\
\hline $\begin{array}{l}\text { CESCR (1992): Committee on } \\
\text { Economic, Social and } \\
\text { Cultural Rights }\end{array}$ & 18 & $15(83 \%)$ & $3(17 \%)$ & $15(83 \%)$ & $3(17 \%)$ \\
\hline $\begin{array}{l}\text { CERD(1986) : Committee on } \\
\text { the Elimination of Racial } \\
\text { Discrimination }\end{array}$ & 18 & $17(94 \%)$ & $1(6 \%)$ & $17(94 \%)$ & $1(6 \%)$ \\
\hline Women's Committee $(1986)$ & 23 & $0(0 \%)$ & $23(100 \%)$ & $2(7 \%)$ & $21(91 \%)$ \\
\hline $\begin{array}{l}\text { CAT (1988): Committee } \\
\text { Against Torture }\end{array}$ & 10 & $8(80 \%)$ & $2(20 \%)$ & $6(60 \%)$ & $4(40 \%)$ \\
\hline $\begin{array}{l}\text { Children's Committee }(1992) \\
(10 \text { original) }\end{array}$ & $5(50 \%)$ & $5(50 \%)$ & $9(50 \%)$ & $9(50 \%)$ \\
\hline $\begin{array}{l}\text { MWC (2005): Migrant } \\
\text { Workers Convention }\end{array}$ & 10 & $8(80 \%)$ & $2(20 \%)$ & $7(70 \%)$ & $3(30 \%)$ \\
\hline $\begin{array}{l}\text { CRPD (2008): Committee } \\
\text { on the Rights of Persons } \\
\text { with Disabilities }\end{array}$ & 12 & $7(58 \%)$ & $5(42 \%)$ & $7(58 \%)$ & $5(42 \%)$ \\
\hline $\begin{array}{l}\text { SPT (2009): Subcommittee } \\
\text { on Prevention of Torture }\end{array}$ & 10 & $9(90 \%)$ & $1(10 \%)$ \\
\hline
\end{tabular}

Moreover, the latest World's Women Trend and Statistics indicate that women are also relatively underrepresented in international and regional courts, though women's representation tends to be slightly better in the case of human rights bodies. ${ }^{79}$ The highest share is seen in ICC, where seven of 18 judges (39\%) were women as the Rome Statute of the International Criminal Court (hereinafter Rome Statute) called for a fair representation of female and male judges. ${ }^{80}$ Overall, there

77 Id.

78 A. Edwards, Violence against Women under International Human Rights Law 98 (2011).

79 U.N. Doc. ST/ESA/STAT/SER.K/19.

80 Rome Statute art.36(8)(a)(iii). U.N. Doc. A/CONF.183/9. Lobbying by nongovernmental organizations and the support of sympathetic States helped bring about the realization of this regulation. See D. TerriEs ET AL, The InTERnAtional JUdGE 19 (2007). In contrast, the International Tribunal for the Law of the Sea was composed entirely of male judges, while in the International Court of Justice only $7 \%$ of the judges were women at the end of 2010. See U.N. Doc. ST/ 
is a considerable degree of disparity between the number of men and women in various fields and decision-making at the global level. While Resolution 1325 recognizes the urgent need to mainstream a gender perspective on a comprehensive range, it is not quite comprehensive enough as there is no reference to the structural causes of women's inequality, such as women's economic marginalization, which must be addressed before the "rhetoric of participation" has any hope of being translated into practice. ${ }^{81}$ Since the adoption of Resolution 1325 , nearly a decade has passed for the Security Council to ensure the commitments and follow-ups with a series of resolutions on women. ${ }^{82}$

The Security Council Resolution 1820 was again unanimously adopted in 2008 to address the issue of widespread sexual violence committed particularly against women and children as a tactic of war during and after armed conflict. ${ }^{83}$ Resolution 1820 has some distinctions as follows. First, the scope of subject matter is much narrower than Resolution 1325, because Resolution 1820 only emphasizes the situations regarding the special needs of women and girls. ${ }^{84}$ As the subject is confined to a specific group - women and girls - Resolution 1820 is, in consequence, silent about sexual violence against men and boys. It is reasonable on the part of the Security Council to give greater protection to women and girls, because they constitute approximately $80 \%$ of people displaced by conflict or human rights violations. ${ }^{85}$ Such perception of women as victims, however, can be problematic as it puts more emphasis on the protection of women than the elimination or prohibition of gender-oriented atrocities. Therefore, Resolution 1820, by and large, focuses only on the vulnerability of women by subjecting them to protection of State and the international community. Too much focus on 'vulnerability' is definitely in conflict with current feminist approaches to international law, which promotes the empowerment of women, as foreseen in the Resolution 1325.

Second, the requirement of State-specific sanctions against parties who commit

ESA/STAT/SER.K/19, at 121 .

81 Supra note 13, at 106-107.

82 Supra note 15.

83 S.C. Res. 1820, U.N. Doc. S/RES/1820 (2008).

84 Id. ๆ 4. It reads: “...calls upon Member States...to ensure that all victims of sexual violence, particularly women and girls have equal protection." $\mid 5$ reads: “... affirms its intention to take into consideration the appropriateness of targeted and graduated measures against parties to situation of armed conflict who commit rape and other forms of sexual violence against women and girls in situations of armed conflicts." Paragraph 14 of Resolution 1820 reads: “... to consider developing and implementing policies... for the benefit of women and girls affected by sexual violence in armed conflict."

85 See Security Council Resolution 1325 Annotated, United Nations Development Fund for Women, available at http:// www.peacewomen.org/assets/file/BasicWPSDocs/annotated_1325.pdf(last visited on Sept. 21, 2013). 
sexual violence during armed conflict may implicate further military engagement. In this respect, Otto presents a potential danger as such potential military engagement may justify the Security Council's use of power for the purposes of achieving feminist goals. $^{86}$

Third, the threshold for the recognition of international crime is ambivalent. It states, e.g., "rape and other forms of sexual violence can constitute a war crime, a crime against humanity or a constitutive act with respect to genocide." ${ }^{87}$ The use of the word, 'can,' though may be helpful to alleviate the threshold for the prosecution of sexual violence, is in fact quite retrogressive because sexual violence is already recognized as such in international law. ${ }^{88}$

Following the previous resolutions, in 2009, the Security Council adopted Resolution 1888 concerning women, peace and security. A notable difference of this resolution from Resolution 1820 is that Resolution 1888 is more inclusive regarding the category of victims by demanding that: "All parties to armed conflict immediately take appropriate measures to protect civilians including women and children." ${ }^{89}$ In contrast, Resolution 1820 used the term 'particularly' to refer to women and on numerous times used the expression "women and girls" as subjects of protection in armed conflict. ${ }^{90}$ Thus, Resolution 1888 addresses sexual violence within a much broader agenda of gender mainstreaming. ${ }^{91}$ In the same year, the Security Council adopted Resolution 1889, urging that: "Member States, international and regional organizations take further measures to improve women's participation during all stages of peace processes, particularly in conflict resolution, post-conflict planning and peace building, including by enhancing their engagement in political and economic decision-making at early stages of recovery processes. ${ }^{\text {2 }}$ Rather than emphasizing the protective status of women in armed conflict, this resolution equally stresses women's active participations as part of empowerment process.

Most recently, the Security Council passed Resolution 1960 in $2010 .^{93}$ It embraces the commitments in previous resolutions. Resolution 1960 strongly urges to take more feasible measures to ensure full implementation of the previous commitments.

86 Supra note 13, at 109.

87 Supra note 83, ๆ 4. [Emphasis added]

88 For details, see A. Barrow, UN Security Council Resolutions 1325 and 1820: constructing gender in armed conflict and international humanitarian law, 92 INT'L REv. Red CRoss 221-234 (2010).

89 S.C. Res. 1888, U.N. Doc. S/RES/1888, ๆ 3 (2009).

90 S.C. Res. 1820, U.N. Doc. S/RES/1820, ๆ 4, 5 \& 9 (2008).

91 S.C. Res. 1889, U.N. Doc. S/RES/1889, ๆ 1 (2009).

92 Id.

93 S.C. Res. 1960, U.N. Doc. S/RES/1960 (2010). 
In particular, Paragraph 10 of Resolution 1960 requires the inclusion of criteria pertaining to acts of rape and other forms of sexual violence when adopting or renewing targeted sanctions. It also calls upon all relevant UN missions and bodies to share all pertinent information about sexual violence with the UN Security Council Sanction Committee's monitoring groups. ${ }^{94}$ The foregoing resolutions are indisputably welcoming steps forward to recognize the visibility of gender in situations of armed conflict. Generally, the purpose for these resolutions is twofold: one is to maintain the balance between protection and empowerment of women, the other, to increase women's participation. With respect to the latter purpose, more viable solutions for the fundamental changes in the existing system, other than mere proposals to enhance women's representation, are required to best safeguard women's rights. ${ }^{95}$ In this respect, as Charlesworth correctly points out, "the absence of women is more than a simple statistical underrepresentation. ${ }^{96}$

\section{Challenges Ahead}

The last two decades saw a continuous stream of women's concerns being addressed by a number of international instruments, including declarations, the Security Council resolutions, treaties and judgments of international criminal courts. A procedural and substantial inequality has been successfully addressed by feminist scholars, though significant tension still remains. Currently, a central feminist project continuously oscillates between existing norms and new agenda. Understanding such intrinsic tension between resistance and compliance is thus vital to a feminist critique of international law. The focus of the critique should not be confined to solve the tension; it is more optimal to properly identify the two interacting movements and discern whether or how such tensions actually exclude women's voices.

Gender mainstreaming policies are now a declared priority within the UN. However, the question of 'mainstreaming' seems to remain somewhat unresolved. They continue to find out whether transformative force from outside operate more

$94 \quad I d .910$.

95 This brings a classic question whether women's rights are best protected through general norms or through specific norms applicable only to women. Charlesworth argues: "The attempt to improve women's lives through general laws can allow women's concerns to be submerged in more global issues, but this price of creating separate institutional mechanisms for women has been the building of a women's ghetto with less power, resources and priority than the general human rights bodies." See supra note 47, at 1.

96 Supra note 19. 
effectively than within the current structures to implement such policies.

Another challenge is related to the tension between feminism and the mainstream as well as among feminists themselves. The former refers to whether the feminist debate is reinforced or loses its vitality by intersecting with other 'mainstream' projects. It is apposite to continuously engage in the mainstream because its synergy will outweigh any potential and partial loss of feminist visibility. The latter tension is relevant to the issue whether there exists a single 'women's voice' from the perspective that feminist legal scholarship is mostly derived from 'Western' concerns. In other words, critique of the critique exists among the circles of feminist as Brooks claims that "one woman's bread is another woman's poison." ${ }^{97}$ The evidence of fragmentation among feminist perspectives brings back the long debate of whether women's rights should be explicitly distinguished from human rights and thus generates the question of universality and relativism in international human rights law. ${ }^{98}$ However, further discussion on relativism and universality of human rights is beyond the scope of this article.

\section{Conclusion}

This article has primarily sought to evaluate the triumph of the feminist legal scholars and examine whether the UN's gender mainstreaming policy has been a successful mechanism for integrating feminist principles into the institution. When gender is discussed as an international discourse, it is generally relegated to the human rights law sphere. The Security Council resolutions on women, peace and security reflect the inherent tension between resistance and compliance because these resolutions incorporate women's concerns, yet in a very restrictive scope. Resolution 1325 was a milestone for the UN to address the gender mainstreaming. It supports protection and empowerment of women and calls for the fair representation of women in important decision-making processes at international level.

However, the subsequent resolutions seem to be much narrower in their scope of application as women are categorized and even 'stereotyped' as victims so that

97 R. Brooks, Feminism and International Law: An Opportunity for Transformation, 14 YaLe J.L. \& Feminism 353 (2002). There are many literatures on so-called "Third World Women's Perspective." It is praiseworthy to the extent that feminist legal scholarship worked to identify the different needs, yet the term, 'Third World' itself sounds conceited to the extent that this particular view is somewhat outside circle of the Western mainstream of feminism.

98 See generally C. Chinkin, Feminism, Approach to International Law, in 4 Max Planck Encyclopedia of Public INTERNATIONAL LAW 4-7 (R. Wolfrum ed., 2012). 
their focus might be much more on the 'protection' rather than 'empowerment' of women. Moreover, while these resolutions require the relevant UN bodies to periodically monitor the situations particularly involving violence against women, they are silent to any accountable mechanism available, which is, in fact, a prevailing problem in exiting international human rights institution. As far as the women's fair representation is concerned, it should be pointed out that gender balance can be ultimately achieved through both identification of all the necessary contextual factors and education to remove gender bias rather than through the quotas. By these steps, the final goal to achieving the gender balance in both qualitative and quantitative aspects will be realized. 